Editorial

\title{
Neurografía por resonancia magnética, algunas observaciones sobre un método de imágenes poco difundido
}

\author{
Neurography by Magnetic Resonance, some Inputs about a Little \\ Widespread Method
}

\author{
Claudia Cejas ${ }^{1}$ \\ 1 Jefa del Departamento de Diagnóstico por Imágenes, Instituto de \\ Investigaciones Neurológicas Dr. Raúl Correa, FLENI, Buenos Aires, \\ Argentina
}

Rev Argent Radiol 2018;82:105-106.

Históricamente, el sistema nervioso periférico y las estructuras circundantes fueron estudiadas por medio del ultrasonido (US) y la resonancia magnética (RM); en el caso de la RM, a través del empleo de secuencias convencionales en ponderación T1, T2 y STIR. Fue hacia el año 2010 que Chhabra y su equipo ${ }^{1}$ (en aquel entonces, en el Hopkins Hospital), comenzaron a optimizar los protocolos de estudio en RM, con secuencias tridimensionales submilimétricas en equipos de alto campo, en particular 3Tesla. Así nació lo que denominaron neurografía (neurography en inglés) por RM (NRM). Simultáneamente, en otras partes del mundo, se comenzó a trabajar en el tema, inclusive en nuestro país.

Sin entrar en detalles, pues excede el debate de este editorial, la NRM brinda información sobre la ultraestructura del nervio y permite ver desde la presencia de leve edema neural hasta lesiones extremas, como sección completa de un nervio o tumores. Las secuencias neurográficas se han optimizado y se complementan con secuencias de difusión y de tensor de difusión que aportan datos cuantitativos de valor a los morfológicos de las imágenes de NRM. Además, como información extra, se observan los cambios denervatorios en los diferentes estadios evolutivos de los músculos dependientes del nervio afectado. ${ }^{2,3}$

Ahora bien, ¿cuál es el alcance de la neurografía como método diagnóstico en las neuropatías y plexopatías? En primer lugar, es necesario reconocer que no es un método cruento, hecho que lo diferencia en gran medida de los estudios electrofisiológicos. Algunos neurólogos argumentan que la NRM es un método engorroso pues conlleva más tiempo que un estudio de RM convencional. Sin embargo, el estudio electromiográfico no lleva menos de 20 minutos o media hora, además de generar molestias al paciente. Por su parte, algunos radiólogos argumentan que la NRM es un estudio muy dedicado, en donde es imprescindible la presencia del médico, lo cual consume tiempo y por lo tanto, dinero. Es efectivamente así al principio, como toda nueva técnica de imagen, pero luego de repetirlo en la práctica diaria, los técnicos radiólogos aprenden a programarlo sin mayores problemas, sobre todo con el empleo de secuencias neurográficas tridimensionales.

Entonces, ¿cuál es mejor método de imágenes para la evaluación de los nervios periféricos y plexos, el US o la RM? La respuesta es intuitiva, cualquiera de los dos, si se realiza con manos expertas y un equipamiento óptimo. Sin embargo, ¿operaría un cirujano una lesión de plexo sin una RM previa? ¿El US le alcanza para conocer el abordaje adecuado y las estructuras adyacentes al nervio comprometido? Habiendo trabajado con ambos métodos durante 30 años me animo a aconsejar la RM como método pre quirúrgico ante una lesión de nervio. Sin embargo, los años y el desarrollo de equipamiento más "performante" nos dirá quién gane. Otra vez el debate excede este editorial.

Por último, ¿a quién le corresponde hacerse cargo de esos estudios? El sistema nervioso periférico es la extensión del sistema nervioso central, por ello los neuroradiólogos consideran que deberían estar en sus manos o más bien "bajo sus ojos." Por otro lado, los radiólogos músculo-
Address for correspondence Claudia Cejas, MD, Departamento de Diagnóstico por Imágenes, Instituto de Investigaciones Neurológicas Dr. Raúl Correa, FLENI, Buenos Aires, Argentina (e-mail: claudia.cejas@gmail. com).
DOI https://doi.org/

10.1055/s-0038-1668121.

ISSN 1852-9992.

Copyright $\odot$ 2019, Sociedad Argentina de Radiología. Publicado por Thieme Revinter Publicações Ltda., Rio de Janeiro, Brazil. Todos los derechos reservados.
License terms

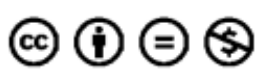


esqueléticos, al conocer a la perfección el área en estudio, la anatomía en las imágenes convencionales, consideran que son ellos quienes debieran interpretarlas. Entonces, ¿a quién le corresponde? Permítanme decirles que a quien mejor lo haga, al que se apasione por el tema, se interese por la clínica de las neuropatías y por supuesto, a quien tenga la oportunidad.

Les deseo un muy buen Congreso CADI 2018. Hasta el próximo número.

\section{Bibliografía}

1 Chhabra A, Lee PP, Bizzell C, Soldatos T. 3 Tesla MR neurographytechnique, interpretation, and pitfalls. Skeletal Radiol 2011;40(10): 1249-1260

2 Aguilar M, Caneo N, Falcón L, Rollán C, Chaves H. Neurografía por resonancia magnética en 3T: experiencia preliminar. Rev Argent Radiol 2012;76(04):288-295

3 Jeon T, Fung MM, Koch KM, Tan ET, Sneag DB. Peripheral nerve diffusion tensor imaging: Overview, pitfalls, and future directions. J Magn Reson Imaging 2018;47(05):1171-1189 